\title{
Yield of subterranean clover after post-emergence herbicide application for broadleaf weed control
}

\author{
Breanna J. O. TAYLOR, Rainer W. HOFMANN and Derrick J. MOOT* \\ Lincoln University, Field Research Centre, Faculty of Agriculture and Life Sciences, \\ PO Box 85084, Lincoln 7647, New Zealand \\ *Corresponding author: Derrick.Moot@lincoln.ac.nz
}

\begin{abstract}
A field experiment was established in Lincoln, Canterbury in autumn 2018 to evaluate the effect of acetolactate synthase (ALS) inhibiting herbicides on subterranean (sub) clover. Two herbicides, imazethapyr and flumetsulam, were applied to seven sub clover cultivars at the 4-5 trifoliate leaf stage during July 2018. By December 2018, both herbicides had reduced the broadleaf weed yield by $1000 \mathrm{~kg} \mathrm{DM} / \mathrm{ha}$. Sub clover herbage yield in spring (3 Oct 2018) increased only for 'Antas' and 'Napier' cultivars but all cultivars had an increase in total annual herbage yield when herbicides were applied. Plots were managed for seed set so reestablishment was examined. Imazethapyr had a longer residual than flumetsulam, with greater control of broad-leaved dock (Rumex obtusifolius) eight months after application. Herbicide application had no effect on subsequent sub clover emergence the following year. This experiment demonstrated the potential to establish a pure sward of sub clover with the use of ALS inhibiting herbicides, which could be used to create a high legume base pasture before overdrilling grass the following year.
\end{abstract}

Keywords: Trifolium subterraneum, canopy cover, light interception

\section{Introduction}

Subterranean (sub) clover (Trifolium subterraneum L.) is the most commonly sown winter-spring annual legume in New Zealand (Monk et al. 2016). It is used in summer dry areas where white clover (T. repens L.) fails to thrive (Knowles et al. 2003). Sub clover has high growth in early spring compared with other perennial legume options, which coincides with the high feed demand of lactating ewes (Brown et al. 2006). Incorporating sub clover into a farming system has been shown to increase pre-weaning lamb growth rates by $\sim 30 \%$ and therefore increase prime lamb numbers on dryland farms (Grigg et al. 2008).

Establishing sub clover monocultures in autumn could provide ewes with high-quality feed in early spring, and allow a large seed bank to build up before grass is introduced the following autumn. This temporal separation of species has been advocated previously to successfully establish slow emerging species (Hurst et al. 2000). Establishing a pure sward of sub clover requires adequate post-emergent broadleaf weed control because it is sensitive to competition for light (Smetham 2003). Only one herbicide, Headstart ${ }^{\circledR}$ (a.i. flumetsulam), is currently recommended for use on sub clover in New Zealand (Novachem 2019). Most herbicide manuals provide a comment on tolerance by 'clover' with no qualification, so it may be assumed that this is related to white clover. Research on post-emergence herbicide use on sub clover has predominantly occurred in Australia where monocultures of sub clover are more commonly established. However, differences in climate, soil types, farming systems and the range of weed species means that New Zealand specific research is required.

Historically, MCPB (4-(4-chloro-2-methylphenoxy) butanoic acid) and 2,4-DB (4-(2,4-dichlorophenoxy) butanoic acid) have been recommended for broadleaf weed control when establishing legume-based pastures. Results have shown that these herbicides can cause losses of sub clover yield up to $62 \%$ (Evans et al. 1989). More modern herbicides, such as acetolactate synthase (ALS) inhibiting herbicides, have shown potential for use on sub clover. Research in New South Wales, Australia, showed no change in sub clover yield for 'Napier' and 'Dalkeith' cultivars treated with imazethapyr, an ALS inhibitor, but a reduction of yield of $93 \%$ for 'Coolamon'. Thus, there is a need to look at cultivar by herbicide interactions when examining candidate herbicides for use in New Zealand.

The aim of the study was to increase the knowledge base of using ALS inhibiting herbicides for broadleaf weed control on sub clover cultivars available in New Zealand. To do this, an experiment was established in the field at Lincoln University, Canterbury. The objective was to quantify the herbage yield response, crop damage and level of weed control achieved.

\section{Materials and Methods}

The experiment was sown at the north end of Iversen 9 field $\left(43.6473^{\circ} \mathrm{S}, 172.4667^{\circ} \mathrm{E}\right)$, at Lincoln University, Canterbury, New Zealand. The soil is a Wakanui, silt loam (Udic Ustochrept, USDA Soil taxonomy). A soil sample at the depth of 0-75 $\mathrm{mm}$ was taken on $24 \mathrm{Apr}$ 2018, which indicated a low available sulphur content 
(5 mg/kg). Sulphur Super 30 (Ravensdown, Hornby: N0:P7:K0:S30:Mg0:Ca16) was applied on 11 Sep 2018 at $100 \mathrm{~kg} \mathrm{~S} / \mathrm{ha}$.

The experimental area was previously a pasture of 'Arrow' perennial ryegrass (Lolium perenne L.) and 'Tribute' white clover sown on 26 Aug 2014. On 2 Mar 2018 the area was sprayed with WeedMaster ${ }^{\circledR}$ TS540 (540 g/L glyphosate, Nufarm) at $2 \mathrm{~L} / \mathrm{ha}$. On $26 \mathrm{Mar}$ 2018 , the area was rotary hoed and then rolled with a Cambridge roller 2 days later. On 19 Apr 2018 the area was power harrowed and rolled into a final seed bed a day prior to sowing the experiment.

Seven sub clover cultivars from the three different subspecies were used in the experiment (Table 1). Germination was tested prior to sowing at an incubation temperature of $16^{\circ} \mathrm{C}$. All cultivars had a germination of $>79 \pm 2.0 \%$. Six cultivars were sown at a rate of $20 \mathrm{~kg} / \mathrm{ha}$. 'Napier' was sown at a higher rate of $40 \mathrm{~kg} / \mathrm{ha}$ to account for the seed being lime-coated, which represented $\sim 43 \%$ of the weight. The weight of the coating was determined by the removal of the seed coat from 200 seeds followed by reweighing to determine the total seed weight. The cultivars were sown with a Flexiseeder ${ }^{\circledR} 14$ row air induced plot seeder on the $20 \mathrm{Apr} 2018$ at a $15 \mathrm{~cm}$ row spacing and a target depth of $10 \mathrm{~mm}$. The experiment was a randomised strip plot design with cultivar as Factor A and herbicide treatment as Factor B (Petersen 1985). Each cultivar strip was $7 \times 4.2 \mathrm{~m}$. Two herbicide treatments were applied perpendicular across the cultivar plots which gave 84 plots (experimental units). The herbicide treatments were applied in a $2 \mathrm{~m}$ wide strip. The unsprayed control strips were $3 \mathrm{~m}$ wide. Emergence occurred from 1 May 2018.

Weeds were surveyed after the experiment had been sown. The dominant broad-leaved weed species were seedlings of broad-leaved dock (Rumex obtusifolius L.), hedge mustard (Sisymbrium officinale L.) and wire

Table 1 Sub clover (Trifolium subterraneum) cultivars, subspecies and sowing rate used in the experiment at Iversen 9, Lincoln University, Canterbury, New Zealand.

\begin{tabular}{llcc}
\hline Cultivar & Subspecies & $\begin{array}{c}\text { Sowing rate } \\
\text { (kg/ha) }\end{array}$ & $\begin{array}{c}\text { Germination } \\
\text { (\%) }\end{array}$ \\
\hline 'Antas' & brachycalycinum & 20 & 97 \\
'Coolamon' & subterraneum & 20 & 91 \\
'Denmark' & subterraneum & 20 & 90 \\
'Monti' & yanninicum & 20 & 79 \\
'Napier'* & yanninicum & 40 & 91 \\
'Narrikup' & subterraneum & 20 & 89 \\
'Trikkala' & yanninicum & 20 & 89 \\
\hline
\end{tabular}

* = coated seed, $=23 \mathrm{~kg} / \mathrm{ha}$ of bare seed equivalent. weed (Polygonum aviculare L.). Poa annua L. was the dominant grass weed.

The herbicide treatments (Table 2) were applied on the $04 \mathrm{Jul} 2018$ when all sub clover cultivars were at the 4-5 trifoliate leaf stage. Commercially recommended application rates were used and mixed in $10 \mathrm{~L}$ batches. Spinnaker ${ }^{\mathbb{B}}$ was applied with $1 \mathrm{~L} /$ ha of Uptake ${ }^{\mathrm{TM}}$ spraying oil (Corteva Agriscience). Herbicides were applied with a purpose-built sulky sprayer with a TeeJet ${ }^{\mathbb{R}}$ fan nozzle boom with $2.1 \mathrm{~m}$ spray cover and pressure of $200 \mathrm{kPa}$. The application volume was $200 \mathrm{~L} / \mathrm{ha}$. Herbicides were applied at walking speed on a still day.

\section{Measurements}

Sub clover plants in a randomly chosen $0.2 \mathrm{~m}$ length of drill row in each experimental unit were counted on 4 Sep 2018 to determine plant establishment. Dry matter harvests were taken on 3 Oct, 4 Nov and 6 Dec 2018 by cutting a $0.2 \mathrm{~m}^{2}$ quadrat area to $3 \mathrm{~cm}$ above the soil level in each experimental unit. A subsample was sorted into sub clover, white clover, broadleaf weeds, grass weeds and dead components before drying in a forced air oven at $60^{\circ} \mathrm{C}$ for 48 hours.

After each dry-matter harvest, plots were grazed collectively with mixed aged ewes from 4-8 Oct, 5-7 Nov and 10-12 Dec 2018. The plots were topped postgrazing on 9 Oct 2018 to remove dead weeds that had not been grazed, predominantly in the control plots.

Normalised Difference Vegetation Index (NDVI) was measured using a Trimble ${ }^{\circledR}$ GreenSeeker ${ }^{\circledR}$ Handheld Crop Sensor. Measurements on individual experimental units started on 7 Sep 2018 and were taken every 10-20 days until 6 Dec 2018.

Equation 1, from Oliveira (2015), was used to correct NDVI measurements from the GreenSeeker ${ }^{\circledR}$ where $N D V I_{r}$ is the Index measured, $N D V I_{s}$ is the bare soil Index measurement, $C_{\max }$ is the actual maximum radiation interceptance $(0=$ no canopy, $1=$ fully covered) and $N D V I_{\max }$ is the highest NDVI reading for the plot throughout the season. $C_{\max }$ was considered to

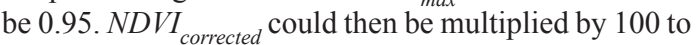
get canopy cover $\%$.

$$
N D V I_{\text {corrected }}=\frac{\left(N D V I_{r}-N D V I_{s}\right)\left(C_{\max }\right)}{N D V I_{\max }-N D V I_{s}} \quad \text { Equation } 1
$$

Table 2 Herbicide application rates used in at Iversen 9, Lincoln University, Canterbury, New Zealand.

\begin{tabular}{llcc}
\hline Herbicide & Manufacturer & $\begin{array}{c}\text { Active } \\
\text { ingredient }\end{array}$ & $\begin{array}{c}\text { Application } \\
\text { rate (L/ha) }\end{array}$ \\
\hline Headstart $^{\circledR}$ & Lonza NZ Ltd. & $50 \mathrm{~g} / \mathrm{L}$ flumetsulam & 1.0 \\
Spinnaker $^{\circledR}$ & BASF NZ Ltd. & $240 \mathrm{~g} / \mathrm{L}$ imazethapyr & 0.4 \\
\hline
\end{tabular}


Sub clover emergence during the autumn after sowing was monitored by seedling counts in a $0.01 \mathrm{~m}^{2}$ quadrat in each experimental unit on the 21 Feb 2019. Dry areas and areas that were dominant in volunteer white clover were avoided. The plots were then sprayed with $5 \mathrm{~L} / \mathrm{ha}$ of $\operatorname{Buster}^{\mathbb{B}}$ (200 g a.i./L glufosinate-ammonium, Bayer) to kill all seedlings to quantify any further emergence. By March 2019, it was too difficult to count individual seedlings and plots were visually assessed using a $0-6$ scale (Table 3) adapted from Teixeira et al. (2018). Plots were categorised by cultivar as there were no observable differences among herbicide treatments and seedling numbers were high.

In autumn 2019, mature broad-leaved dock plants were the dominant weed species, so the residual effect of the herbicide treatments on dock plant density was scored on 15 Mar 2019. A 0-5 scale was used, with 0 meaning no docks and 5 equating to at least 20 plants/ $\mathrm{m}^{2}$.

\section{Statistical analysis}

All results were analysed using Genstat $19^{\text {th }}$ edition. A strip-plot ANOVA was used to analyse 2018 data on seedling establishment, dry matter production, botanical composition and canopy cover. The treatment structure was set as cultivar $\times$ herbicide. Replicates were used for blocking, herbicide treatment for rows and cultivar for columns. Means were separated using Fisher's protected least significant difference (LSD) with a significance level of $\alpha=0.05$.

A one-way ANOVA was used for the 2019 sub clover emergence scores and residual dock control. Replicates were used for blocking and means were separated using Fisher's protected LSD at $\alpha=0.05$. P values of $>0.05$ were deemed to be non-significant.

\section{Results}

Seedling establishment counts on 4 Sep 2018 showed 'Denmark' and 'Coolamon' had the highest $(\mathrm{P}<0.001)$ populations of $\sim 240$ plants $/ \mathrm{m}^{2}$. 'Monti' and 'Antas' had the lowest populations with 110 plants $/ \mathrm{m}^{2}$. The

Table 3

Sub clover emergence scale used at Iversen 9, Lincoln University, Canterbury, New Zealand. Adapted from Teixeira et al. (2018).

\begin{tabular}{lcc}
\hline Score & Seedlings $/ \mathbf{0 . 0 1 \mathbf { m } ^ { 2 }}$ & Seedlings $/ \mathbf{m}^{\mathbf{2}}$ \\
\hline $0-1$ & 2.5 & 250 \\
2 & 5.7 & 570 \\
3 & 8.9 & 890 \\
4 & 12 & 1200 \\
5 & 15 & 1520 \\
6 & $>20$ & $>2000$ \\
\hline
\end{tabular}

remaining cultivars ranged from $165-195$ plants $/ \mathrm{m}^{2}$. Herbicide treatment had no effect $(\mathrm{P}>0.05)$ on seedling population.

At the first harvest on 3 Oct 2018, both herbicide (imazethapyr or flumetsulam) treatments increased $(\mathrm{P}=0.001)$ the herbage yield of 'Antas' and 'Napier' by $\sim 1000 \mathrm{~kg} \mathrm{DM} / \mathrm{ha}$ and $\sim 700 \mathrm{~kg} \mathrm{DM} / \mathrm{ha}$ over the control, respectively (Figure 1). In comparison, the herbage yield of 'Coolamon' increased $(\mathrm{P}=0.001)$ only following treatment with flumetsulam (by $760 \mathrm{~kg} \mathrm{DM} /$ ha compared with the control). Herbage damage to the clover was recorded but had no effect on yield (data not shown). Neither imazethapyr nor flumetsulam had an effect on the sub clover herbage yields of the remaining four cultivars. Imazethapyr and flumetsulam reduced $(\mathrm{P}<0.001)$ the broadleaf weed herbage yields by $\sim 530$ $\mathrm{kg} \mathrm{DM} / \mathrm{ha}$ on average across all cultivars.

After the first grazing, the regrowth of plots measured by the second harvest showed sub clover herbage yield was higher $(\mathrm{P}<0.001)$ in the flumetsulam treatment than imazethapyr or the control (Figure 2). Cultivar also affected $(\mathrm{P}=0.003)$ sub clover herbage yield. 'Napier' had the highest sub clover herbage yield of $1520 \mathrm{~kg}$ $\mathrm{DM} /$ ha compared with 'Antas' which had the lowest (916 kg DM/ha). At the second harvest, broadleaf weed yield was reduced $(\mathrm{P}<0.001)$ by over $50 \%$ following treatment with flumetsulam $(120 \mathrm{~kg} \mathrm{DM} /$ ha) or imazethapyr $(100 \mathrm{~kg} \mathrm{DM} / \mathrm{ha})$ compared with the control. The grass weeds increased $(\mathrm{P}<0.001)$ to $130 \mathrm{~kg} \mathrm{DM} / \mathrm{ha}$ in the flumetsulam treatment compared with $50 \mathrm{~kg} \mathrm{DM} / \mathrm{ha}$ in the control (Figure 2). Overall weed mass was reduced $(\mathrm{P}=0.021)$ in the imazethapyr treatment from $330 \mathrm{~kg} \mathrm{DM} / \mathrm{ha}$ in the control to $140 \mathrm{~kg}$ $\mathrm{DM} /$ ha. Flumetsulam did not differ from the control or imazethapyr at $230 \mathrm{~kg} \mathrm{DM} / \mathrm{ha}$.

At the third and final harvest, imazethapyr treated plots had an increased $(\mathrm{P}=0.026)$ herbage yield of sub clover of $500 \mathrm{~kg} \mathrm{DM} / \mathrm{ha}$ on average across cultivars compared with the control (Figure 3). Flumetsulam did not affect $(\mathrm{P}>0.05)$ the herbage yield of sub clover at this time. There was a herbicide $\times$ cultivar interaction $(\mathrm{P}=0.015)$ for broadleaf weed yield. Flumetsulam or imazethapyr treatments decreased the broadleaf weed yield in plots containing either 'Antas' or 'Coolamon'. Use of flumetsulam reduced the broadleaf weed yield by $\sim 600 \mathrm{~kg} \mathrm{DM} / \mathrm{ha}$ in plots containing either 'Trikkala' or 'Monti'. Imazethapyr treatment reduced the broadleaf weed yield from $800 \mathrm{~kg} \mathrm{DM} / \mathrm{ha}$ to $390 \mathrm{~kg} \mathrm{DM} / \mathrm{ha}$ in the 'Narrikup' plots. Neither herbicide treatment had any effect on the broadleaf weed yield in the 'Denmark' and 'Napier' plots in the third harvest, which averaged $\sim 270 \mathrm{~kg} \mathrm{DM} / \mathrm{ha}$ and $75 \mathrm{~kg} \mathrm{DM} / \mathrm{ha}$ across the herbicide treatments, respectively.

Over the three harvests, total sub clover yield was $4220 \mathrm{~kg} \mathrm{DM} / \mathrm{ha}$ in the control and $\sim 5500 \mathrm{~kg} \mathrm{DM} / \mathrm{ha}$ 
in the imazethapyr and flumetsulam treatments. Total broadleaf weed yield was $\sim 480 \mathrm{~kg} \mathrm{DM} / \mathrm{ha}$ in the herbicide treatments (a reduction of $\sim 1000 \mathrm{~kg} \mathrm{DM} / \mathrm{ha}$ ) compared with $1450 \mathrm{~kg} \mathrm{DM} / \mathrm{ha}$ in the control.
The mean canopy cover for each cultivar on the 8 measurement dates is presented in Figure 4. On the 7 Sep 2018, 'Antas', 'Coolamon' and 'Napier' had the highest $(\mathrm{P}<0.001)$ canopy covers of $>70 \%$. The

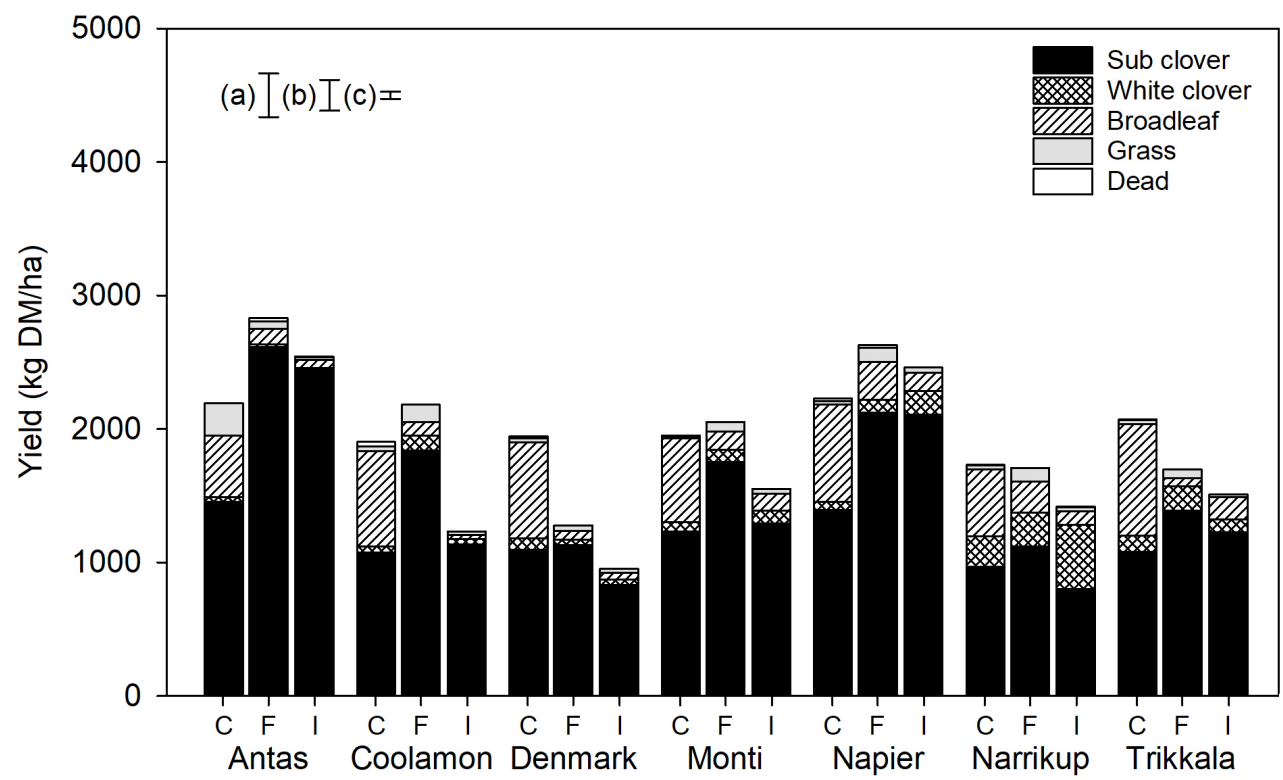

Figure 1 Dry matter (DM) yield of sub clover cultivars on 3 October 2018 after no (control (C)) or imazethapyr (I) or flumetsulam (F) herbicides at establishment, at Iversen 9, Lincoln University, Canterbury, New Zealand. Error bars are the SEM for: (a) cultivar $\times$ herbicide interaction for total DM; (b) cultivar $\times$ herbicide interaction for sub clover DM; (c) the main effect of herbicide for broadleaf weed DM.

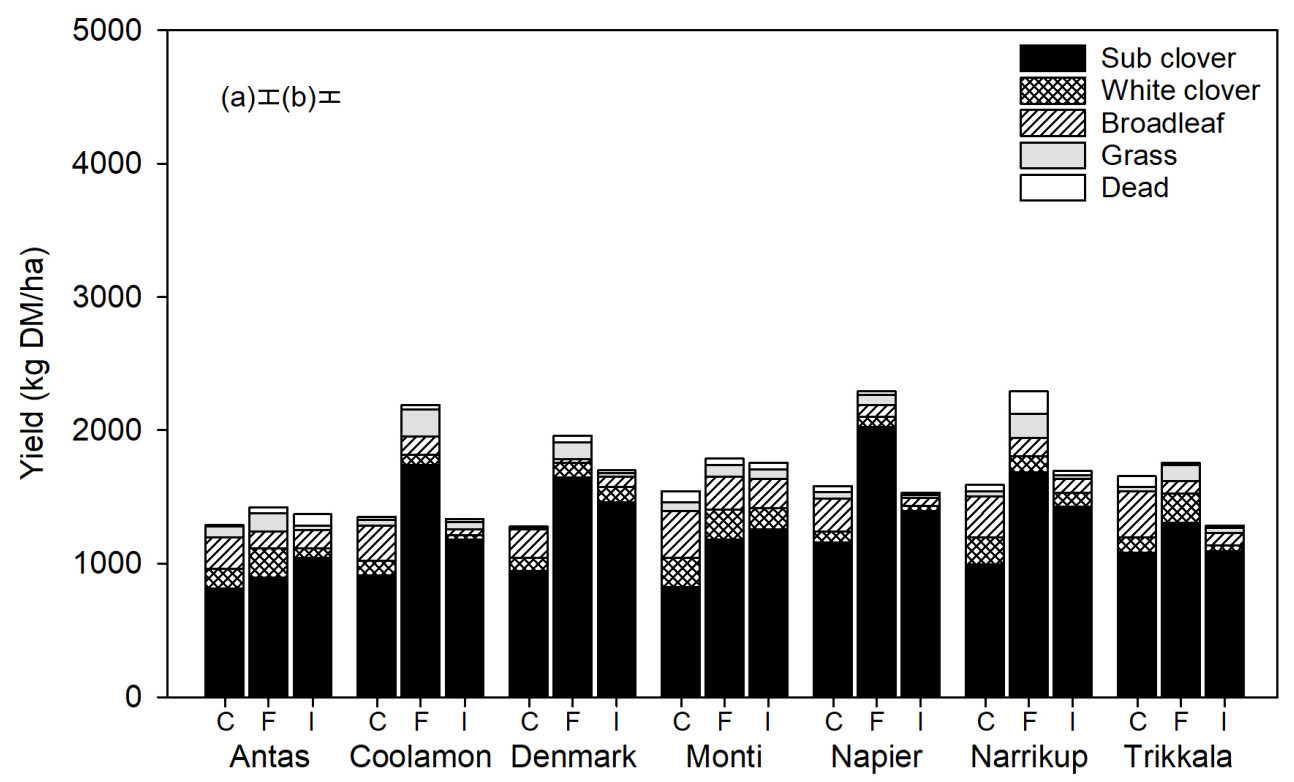

Figure 2 Dry matter (DM) yield of sub clover cultivars on 2 November 2018 after no (control (C)) or imazethapyr (I) or flumetsulam (F) herbicides at establishment, at Iversen 9, Lincoln University, Canterbury, New Zealand. Error bars are the SEM for (a) the main effect of cultivar for sub clover DM; (b) the main effect of herbicide for sub clover DM. 
remaining cultivars ranged from 64-66\%. Canopy cover increased for all cultivars, reaching an average of $95 \%$ on 3 Oct 2018 suggesting that canopy closure had been achieved.
After the first grazing on 16 Oct 2018, 'Antas' had the lowest $(\mathrm{P}<0.001)$ canopy cover of $41 \%$ and 'Denmark' had the highest with $71 \%$. Prior to the next graze canopy cover ranged from $60-68 \%$. Canopy cover was again

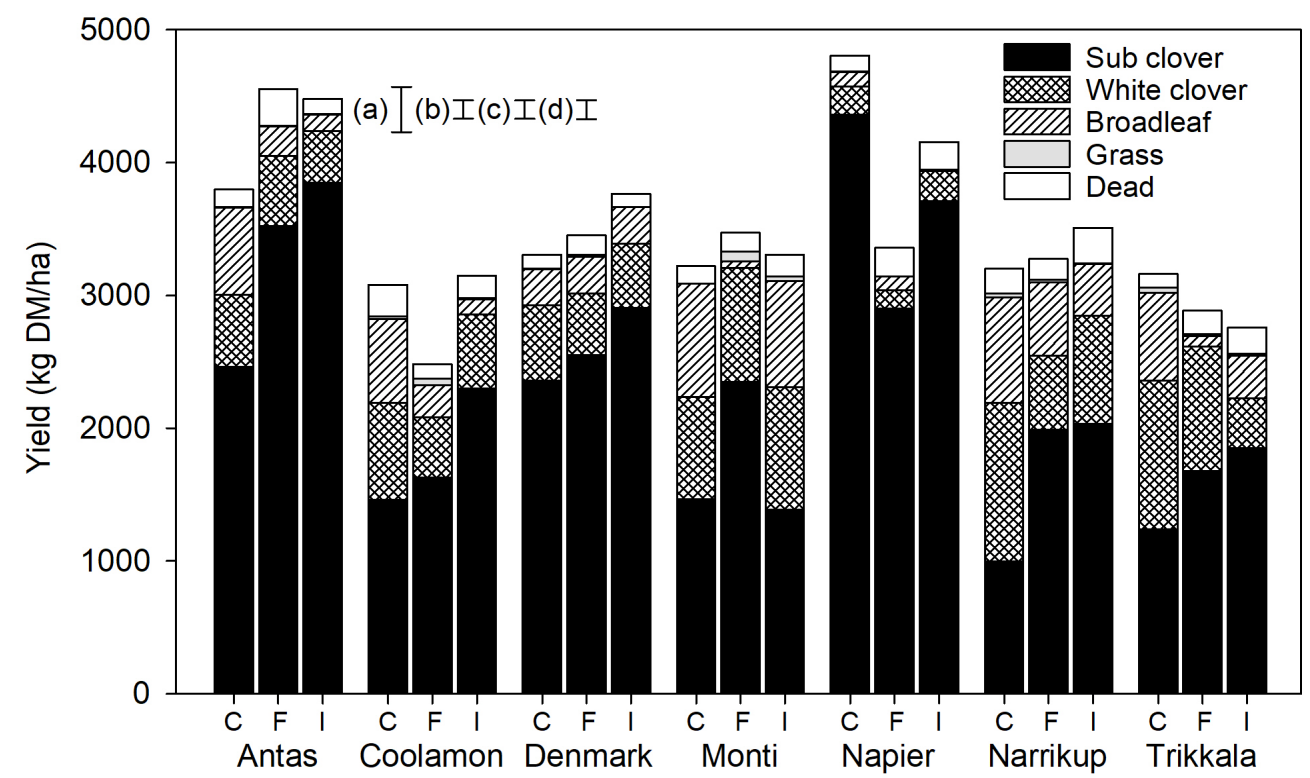

Figure 3 Dry matter (DM) of sub clover cultivars on 6 December 2018 after no (control (C)) or imazethapyr (I) or flumetsulam (F) herbicides at establishment, at Iversen 9, Lincoln University, Canterbury, New Zealand. Error bars are the SEM for: (a) the main effect of cultivar for sub clover DM; (b) the main effect of herbicide for sub clover DM; (c) the main effect of cultivar for white clover DM; (d) the cultivar $\times$ herbicide interaction for broadleaf weed DM.

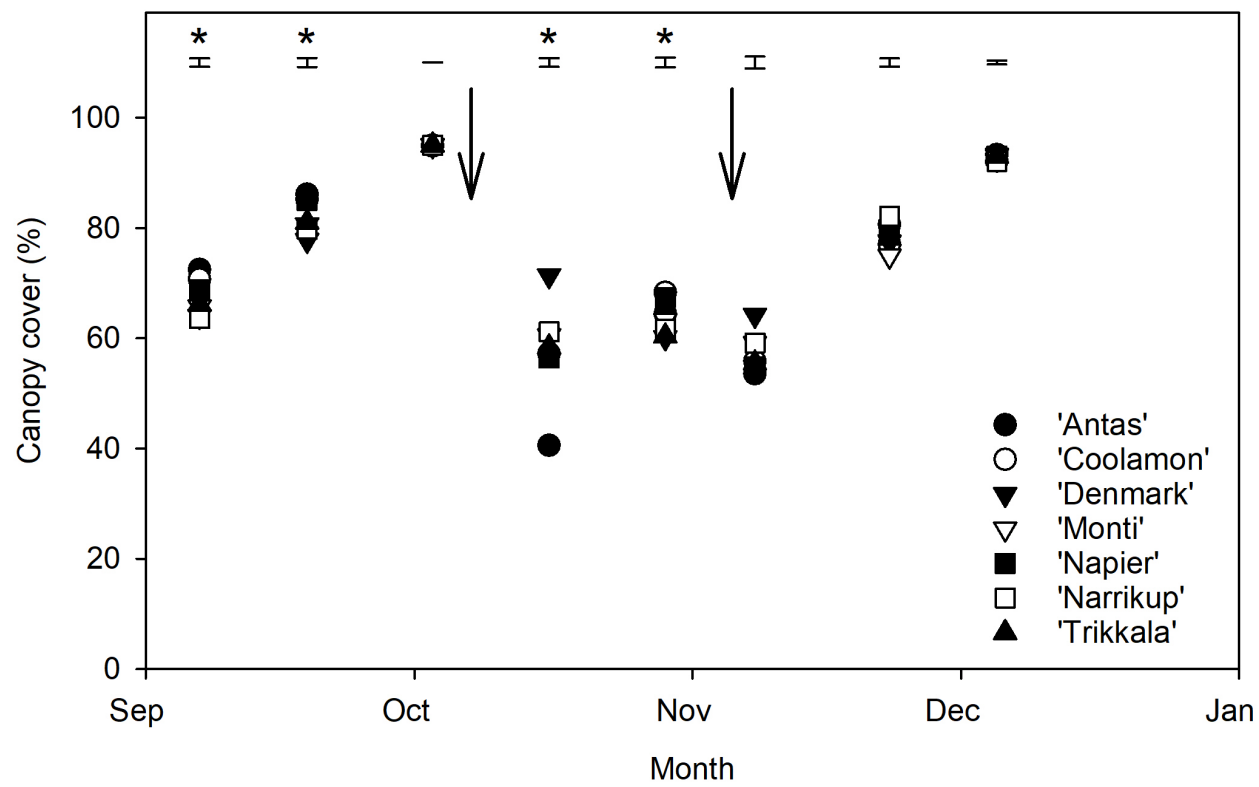

Figure 4 Mean canopy cover (\%) of seven sub clover cultivars from 7 September 2018-6 December 2018 at Iversen 9, Lincoln University, Canterbury, New Zealand. Error bars represent the SEM for the main effect of cultivar. ${ }^{*}=$ significant main effect of cultivar $(P<0.05)$. Arrows indicate grazing dates. 
reduced after grazing, averaging $57 \%$ and increased to $93 \%$ on 5 Dec 2018.

After the summer dry, the 21 Feb 2019 seedling density measurement showed no difference $(\mathrm{P}>0.05)$ in the mean number of seedlings among the cultivars, which ranged between $570-1100$ seedlings $/ \mathrm{m}^{2}$ (Table 4). On 15 Mar 2019, 'Monti' and 'Napier' had the highest $(\mathrm{P}<0.001)$ emergence scores, of 6.00 and 5.75 respectively, while 'Antas' had the lowest emergence score of 1.75 .

Eight months after application, imazethapyr had reduced $(\mathrm{P}<0.001)$ the dock plant density score from 4.3 in the control to 2.1. There was no significant difference between flumetsulam treated plots and the control (4.0).

\section{Discussion}

Application of either imazethapyr or flumetsulam decreased the herbage yield of broadleaf weeds by $1000 \mathrm{~kg} \mathrm{DM} / \mathrm{ha}$ over the season which resulted in an increase in sub clover herbage yield. This increase in herbage yield was greatest for the 'Antas' and 'Napier' cultivars. 'Antas' and 'Napier' had high canopy covers leading up to the October harvest (Figure 4), which allowed these cultivars to take advantage of the space opened in the pasture by the removal of broadleaf weeds. Initially, the herbage yield of 'Coolamon' was increased only by flumetsulam application, even though both herbicides reduced broadleaf weeds by the same amount. This result implies that imazethapyr affected the growth of 'Coolamon'. Therefore, it may be prudent to recommend use of flumetsulam for weed control ahead of imazethapyr for pastures containing 'Coolamon'. This finding is consistent with previous work by Sandral and Dear (2005) who

Table 4

Sub clover seedling $/ \mathrm{m}^{2}$ on 21 February 2019 and emergence score on 15 March 2019 at Iversen 9, Lincoln University, Canterbury, New Zealand.

\begin{tabular}{lcc}
\hline Cultivar & $\begin{array}{c}\text { Seedlings } / \mathbf{m}^{2} \\
21 \text { Feb 2019 }\end{array}$ & $\begin{array}{c}\text { Emergence score* } \\
15 \text { Mar 2019 }\end{array}$ \\
\hline 'Antas' & 570 & $1.75 \mathrm{~d}$ \\
'Coolamon' & 1100 & $5.00 \mathrm{bc}$ \\
'Denmark' & 730 & $5.50 \mathrm{ab}$ \\
'Monti' & 860 & $6.00 \mathrm{a}$ \\
'Napier' & 910 & $5.75 \mathrm{a}$ \\
'Narrikup' & 930 & $4.75 \mathrm{c}$ \\
'Trikkala' & 600 & $5.50 \mathrm{ab}$ \\
P value & 0.398 & $<0.001$ \\
SEM & 67 & 0.27 \\
\hline
\end{tabular}

* Note; Emergence scores were equated to population counts using Teixeira et al. (2018). See Table 3. found 'Coolamon' was most affected by imazethapyr while other sub clover cultivars, such as 'Napier' were unaffected. The herbage yield of the remaining cultivars was not initially increased by the herbicide treatments but total season yield was increased. Thus, any impact of the herbicides on sub clover growth was compensated for by the broadleaf weed control.

After the first grazing, 'Antas' had the lowest yield and canopy cover, due to overgrazing. 'Antas' is a large leafed cultivar with an upright growth habit compared with cultivars such as 'Denmark' that have a prostate growth habit, close to the ground (Widdup \& Pennell 2000). This difference in habit appears to have made 'Antas' susceptible to being overgrazed with the most leaf material consumed. This grazing left only petioles behind, which delayed post-grazing recovery. Specifically, this reduced canopy cover reduced the ability of 'Antas' to intercept light resulting in its low clover yield in the next rotation. In practice, this effect could be avoided by leaving a higher residual for 'Antas' but this was not possible as the experimental plots were grazed in common.

At the third harvest, neither herbicide reduced the broadleaf weeds present in either the 'Denmark' or 'Napier' plots. This result is probably because both controls for these cultivars had a low proportion of broadleaf weeds (Figure 3). The low growth habit of 'Denmark' appeared to shade broadleaf weeds and prevent them from establishing. This effect is also shown by the relatively high canopy cover of 'Denmark' after grazing, when other cultivars had more bare ground, which allowed weeds to establish. It is often recommended to sow two sub clover cultivars together (Lucas et al. 2015). Therefore, 'Denmark' could be sown with another high-yielding sub clover cultivar to help provide ground cover and weed control. The canopy cover of 'Napier' was not as high as 'Denmark' but 'Napier' had higher herbage yields throughout the experiment. 'Napier' appears to have outcompeted the weeds even in the control. NDVI measurements cannot distinguish between clover cover or weed cover so it is likely 'Napier' had higher sub clover cover than some other cultivars leading to its higher yield.

Imazethapyr application resulted in greater control of docks than flumetsulam eight months after application. This finding is consistent with Hollaway et al. (2006) who found imazethapyr degraded more slowly than flumetsulam in the soil. They found $30 \%$ of applied imazethapyr present in the top soil layer after 10 months compared with flumetsulam, which was undetectable in some sites. As imazethapyr had greater residual control, it may improve re-establishment of the clovers the following year, whereas flumetsulam is likely to have no effect.

When seedling re-establishment was measured on 21 
Feb 2019 there was no difference in seedling population among cultivars. There was $51 \mathrm{~mm}$ of rainfall from 1 Jan-21 Feb 2019, with the $21.2 \mathrm{~mm}$ of rain on 14 January being sufficient for germination to occur (Teixeira et al. 2018). All cultivars, apart from 'Antas', had above the recommended minimum of 1000 plants/ $\mathrm{m}^{2}$ required to establish a pure sub clover sward (Smetham 2003). 'Antas' has lower burr burial resulting in seed lying on top of the soil (Nichols et al. 2013) so that the majority of seed may have germinated with the first rain, causing a low seedling population after the induced false strike.

\section{Conclusions/Practical implications/Relevance}

Applications of the herbicides imazethapyr or flumetsulam were equally effective at reducing broadleaf weeds in early spring, which resulted in an increase in sub clover herbage yield for the season. However, the longer soil residual of imazethapyr meant that broadleaf weed control persisted into the following March. Overall, 'Antas' and 'Napier' were the highest yielding sub clover cultivars and the most tolerant to both herbicides. Denmark provided broadleaf weed control even in the control due to its high ground cover and could be sown with a higher yielding cultivar.

Control of broadleaf weeds increased yields of sub clover, which would provide stock with a higher quality feed in spring. Sub clover seedling emergence the following year was unaffected by herbicides. A companion species, such as cocksfoot (Dactylis glomerata) or plantain (Plantago lanceolata), could be overdrilled to create a pasture with high legume content and aid in weed control in the following years.

\section{ACKNOWLEDGEMENTS}

The authors acknowledge $\mathrm{Mr}$ Roland Stead for providing funding and Anna Mills for statistical advice. Funding for this manuscript preparation was provided by Beef + Lamb New Zealand, MBIE, Seed Force New Zealand and PGG Wrightson Seeds under the "Hill Country Futures" research programme (BLNZT1701). The use of chemical trade names does not constitute any recommendation or endorsement.

\section{REFERENCES}

Brown HE, Moot DJ, Lucas RJ, Smith M. 2006. Sub clover, cocksfoot and lucerne combine to improve dryland stock production. Proceedings of the New Zealand Grassland Association 68: 109-115. https:// doi.org/10.33584/jnzg.2006.68.2627

Evans P, Smith R, Carpenter J, Koen T. 1989. Tolerance of subterranean clover cultivars and balansa clover to selective herbicides in Tasmania. Australian Journal of Experimental Agriculture 29: 785-789. https://doi. org/10.1071/EA9890785
Grigg D, Grigg J, Lucas RJ. 2008. Maximising subterranean clover in Marlborough's hill country is key to weaning $80 \%$ of sale lambs prime. Proceedings of the New Zealand Grassland Association 70: 2529. https://doi.org/10.33584/jnzg.2008.70.2727

Hollaway K, Kookana RS, Noy D, Smith J, Wilhelm N. 2006. Persistence and leaching of imazethapyr and flumetsulam herbicides over a 4-year period in the highly alkaline soils of south-eastern Australia. Australian Journal of Experimental Agriculture 46: 669-674. https://doi.org/10.1071/EA04223

Hurst R, Black AD, Lucas RJ, Moot DJ. 2000. Sowing strategies for slow-establishing pasture species on a North Otago dairy farm. Proceedings of the New Zealand Grassland Association 62: 129-135. https:// doi.org/10.33584/jnzg.2000.62.2381

Knowles I, Fraser T, Daly M. 2003. White clover: loss in drought and subsequent recovery. Legumes for dryland pastures. Grassland Research and Practice Series 11: 37-41.

Lucas RJ, Mills A, Wright S, Black A, Moot DJ. 2015. Selection of sub clover cultivars for New Zealand dryland pastures. Journal of New Zealand Grasslands 77: 203-210. https://doi.org/10.33584/ jnzg.2015.77.459

Monk S, Moot D, Belgrave B, Rolston M, Caradus J. 2016. Availability of seed for hill country adapted forage legumes. Hill Country Symposium. Grassland Research and Practice Series 16: 257-267.

Nichols P, Foster K, Piano E, Pecetti L, Kaur P, Ghamkhar K, Collins W. 2013. Genetic improvement of subterranean clover (Trifolium subterraneum L.). 1. Germplasm, traits and future prospects. Crop and Pasture Science 64: 312-346. https://doi.org/10.1071/ CP13118

Novachem. 2019. Novachem New Zealand Agrichermical Manual Retrieved September 2019 from: https://www.novachem.co.nz/

Oliveira JS. 2015. Growth and development of potato (Solanum tuberosum L.) crops after different cool season storage. Unpublished Ph.D thesis, Lincoln University, Canterbury, New Zealand, 321 p. https://researcharchive.lincoln.ac.nz/ handle/10182/6494

Petersen RG. 1985. Design and analysis of experiments. New York, USA: Marcel Dekker, Inc., 429 p.

Sandral G, Dear B. 2005. Weed control options in annual pasture legumes. . Barton, ACT, Australia: Rural Industries Research and Development Corporation, $22 \mathrm{p}$.

Smetham ML. 2003. A review of subterranean clover (Trifolium subterraneum L.): its ecology, and use as a pasture legume in Australasia. Advances in Agronomy 79: 303-350. https://doi.org/10.1016/ S0065-2113(02)79006-8 
Teixeira CS, Lucas RJ, Moot DJ. 2018. Seed yield and subsequent emergence pattern of subterranean clover cultivars in response to summer rain. Journal of New Zealand Grasslands 80: 91-96. https://doi. org/10.33584/jnzg.2018.80.320
Widdup K, Pennell C. 2000. Suitability of new subterranean clovers in the Canterbury region. Proceedings of the New Zealand Grassland Association 60: 161-165. https://doi.org/10.33584/ jnzg.2000.62.2367 